\title{
Impact of Media Utilization and Network Homogeneity on The Creative Expressive Ability of Digital Native
}

\author{
Eunjoo $\mathrm{Kim}^{1}$ \\ ${ }^{1}$ Professor, Education Phychology, Eulji University, Republic of Korea \\ kej70@eulji.ac.kr
}

\begin{abstract}
The purpose of this study is to present the direction of smart education from the perspective of digital native familiar with digital devices. To this end, this study analyzed how media utilization and network homogeneity among the characteristics of digital native affect creative expression ability. To that end, the research was conducted on 320 university students participated in the study from four-year $E$ universities in Gyeonggi-do. The data analysis method for this study was using the IBM SPSS Statistics 20.0 program and stepwise multiple regression analysis were performed. stepwise multiple regression analysis was conducted to identify the influence of media utilization and network homogeneity that affected creative expression capabilities. The results of the study showed, first, that immediately and communication among the sub-factors of media utilization affect creative expression ability. Second, among the sub-factors of network homogeneity, network utilization strength and social homogeneity have been shown to affect creative expression ability. A technical and educational approach to media utilization measures should be taken to enhance immediateness and communication in the use of media in digital native. Furthermore, increasing the frequency of using the network in a way that does not cause collective polarization on the network and forming a group-oriented community with high social homogeneity are also recognized as an open-innovation paradigm required by the digital native generation.
\end{abstract}

Keywords: Digital native, Media utilization, Network homogeneity, Creative expressive ability

\section{Introduction}

Open innovation paradigms and the digital native generation that were born and raised in the digital environment are the generations that can use the Internet, computers, and smartphones in everyday life, not technology. Georgescu-Roegen's study argued that the human ability to expand technology and intellectual domain should not be underestimated [1]. As a future talent, digital native use digital devices not only in life but also in educational fields in expanding technology and knowledge. In the education market, where the use of digital devices is rapidly expanding, students' motivation for learning and class participation rates should be promoted, and the direction of smart education should be presented from the perspective of a digital native. In particular, it is necessary to look for new education methods from the perspective of digital natives and check the impact of network homogeneity of

Article history:

Received (September 15, 2020), Review Result (October 19, 2020), Accepted (December 1, 2020) 
digital natives living in the era of open innovation in SNS environment on creative expression ability. Network homogeneity means the psychological homogeneity within the network to which SNS (Social networking services) users belong. And while the definition of creative expression ability varies, in this work, the definition of creative expression means the ability to generate unique ideas and produce new and appropriate products in new perspectives.

In the social environment of SNS, networks can change society and empower the opinions of the few who are isolated in a pluralistic society, and also become a tool for a number of powerless people. However, social networking sites are misused socially, causing homogeneity on the network, causing social problems, and huge confusion if linked to collective dramatization [2]. Network homogeneity refers to the homogeneity that SNS users feel psychologically within their networks [3]. Network homogeneity consists of ideological homogeneity and social homogeneity. Ideological homogeneity means the homogeneity of political and social beliefs or beliefs felt by users within SNS users' networks. Social homogeneity refers to the homogeneity of social characteristics (age, educational background, economic background) that users feel psychologically within the network of SNS users [3]. In particular, among the characteristics of a digital natives, ideological homogeneity and social homogeneity are shown on SNS networks. Norris said that because of the network characteristics of SNS, digital natives strengthen the beliefs and interests shared on SNS networks [4]. There are not many such network homogeneity studies. Therefore, this research is meaningful in terms of preparing for an open era of innovation.

In addition, in the open innovation paradigm, the use of media is becoming more diverse, with a wealth of media devices [5]. In particular, the digital native generation has limited absolute time for media utilization, so it is more effective and efficient to use media, so they search for related news through computers or smartphones, and communicate with friends through SNS. Existing studies related to media utilization of digital natives focused on personal factors such as personality variables and values rather than on media utilization for comparative analysis with other generations [6][7][8][9][10].

Therefore, this study analyzed how media utilization and network homogeneity among the characteristics of digital native affect creative expression ability.

The research issues for this purpose are as follows.

First, what is the impact of digital native media utilization on creative representation?

Second, what is the impact of digital native network homogeneity on creative representation?

\section{Literature reviews}

Digital natives refers to a generation that freely uses digital devices, such as computers and the Internet, like natives speakers, and is the first term used by Marc Prensky (2001) [11]. Williams (2015) refers to digital natives as the Alpha generation and says they will grow with digital devices, cannot live without smartphones, and can transmit their thoughts online in time [12]. They interact with digital technology at a younger age than other generations due to mobile devices and touch screens, and a close attachment to technology and networks is forming for them to become part of their lives, not tools [13].

American futurist Stan Davis calls today's global village a "network economy" or an "adjacent economy" in his book "Future Governance." According to him, the access economy created by the spread of the Internet and digital technology is shifting to an open innovation paradigm through three features: speed, access, and intangible value. Digital natives are 
quickly and easily getting various information through different creativity, challenges to new things, speed, and various media utilization.

\section{Methodology}

\subsection{Subjects}

The study was conducted on 320 students from the four-year E University in Gyeonggi-do. The general characteristics of the study subjects were shown in [Table 1].

Table 1. General characteristics $(n=303)$

\begin{tabular}{|c|c|c|c|}
\hline \multirow{2}{*}{ Observation variable } & Frequency & $\%$ \\
\hline \multirow{3}{*}{ Gender } & Female & 235 & 77.6 \\
\cline { 2 - 4 } & Male & 68 & 22.4 \\
\hline \multirow{3}{*}{ Grade } & Frist & 138 & 45.5 \\
\cline { 2 - 4 } & Second & 84 & 27.7 \\
\cline { 2 - 4 } & Third & 35 & 11.6 \\
\cline { 2 - 4 } & Fourth & 46 & 15.2 \\
\hline
\end{tabular}

\subsection{Research instrument}

The measurement tools in this study were first composed of questions about General characteristics and questions about media utilization, network homogeneity, and creative expressive ability.

The measure tool for media utilization used a digital media utilization diagnostic scale with the validity of Hwang Young-mi's research [14]. The sub-factors of digital media utilization consist of a total of 14 questions, including expressiveness, instantly, communicability, and immersion.

The network homogeneity measurement tool was developed by Na Eun-kyung, Ryu Jungho, and Lee Dong-ho [15][16]. The sub-factors of network homogeneity consist of a total of 12 questions, with SNS utilization strength, ideological homogeneity, and social homogeneity.

A total of 42 questions were used to measure the level of media utilization ability and network homogeneity affecting creative expression capabilities. The question composition of the measuring tool is shown in [Table 2].

\subsection{Data analysis}

For data analysis, the IBM SPSS Statistics 20.0 program was utilized. First, frequency analysis was performed to examine the average and standard deviation of the demographic and sociological factors and measurement variables of the surveyed persons, and the Cronbach's coefficient value was calculated to ensure the reliability of the measurement tool. Besides, stepwise multiple regression analysis was conducted to identify the influence of media utilization and network homogeneity that affected creative expression capabilities.

\section{Results}

\subsection{The Impact of digital native media utilization on creative expressive ability}


The results of stepwise multiple regression analysis of media utilization for creative expressive ability are shown in [Table 3].

Table 2. Question composition and reliability coefficient of measurement tools

\begin{tabular}{|c|c|c|c|}
\hline \multicolumn{2}{|r|}{ Division } & \multirow{2}{*}{$\begin{array}{c}\begin{array}{c}\text { Number of } \\
\text { questions }\end{array} \\
2\end{array}$} & \multirow{2}{*}{$\begin{array}{c}\text { Cronbach' } \alpha \\
-\end{array}$} \\
\hline General characteristics & Gender, Grade & & \\
\hline Media utilization & $\begin{array}{l}\text { Expressiveness 5item, instantly 3item, } \\
\text { communicability 2item, and immersion 3item }\end{array}$ & 13 & .899 \\
\hline Network homogeneity & $\begin{array}{l}\text { SNS utilization strength } 5 \text { item, network } \\
\text { ideological homogeneity } 4 \text { item, network } \\
\text { social homogeneity } 3 \text { item }\end{array}$ & 12 & \\
\hline $\begin{array}{l}\text { Creative expressive } \\
\text { ability }\end{array}$ & $\begin{array}{l}\text { Creative character and attitude 5item, } \\
\text { creative problem-solving 5item, and } \\
\text { convergence thinking 5item }\end{array}$ & 15 & .903 \\
\hline
\end{tabular}

Table 3. Analysis of variance $(n=303)$

\begin{tabular}{|c|c|c|c|c|c|}
\hline & Sum of squares & df & Mean square & $\mathrm{F}$ & $\mathrm{p}$ \\
\hline Regression Model & 6.668 & 2 & 3.334 & 7.679 & .001 \\
\hline Residual & 34.735 & 80 & .434 & & \\
\hline Total & 41.404 & 82 & & & \\
\hline
\end{tabular}

As a result of the statistical significance test of a model that measures the influence of creative expressive ability with four independent variables consisting of immersion, expressiveness, instability, and communication, which are sub-factor of media utilization, the F statistic value of the model that includes instant and communicability was excluded due to lack of immersion and expressiveness, and the significance rate is .001, which is a significant representation of creative ability at the significant level .05.

Although these results are independent variables that affect the ability of creative expression in the sub-factor of media utilization, it is important to be careful to generalize the results of the study since $14 \%$ can be predicted. Therefore, I can see that for digital native media utilization capabilities, the influence on creative expression capabilities is low.

Also, the results of the statistical significance analysis and contribution of individual independent variables to the use of media for creative expressive ability are shown in [Table 4].

As a result of testing the contribution and statistical significance of the dependent variables of individual independent variables, the independent variables that significantly affect their creative expressive ability at a significant level of .05 are instantly $(\mathrm{t}=3.91, \mathrm{p}=) .000)$, communicability $(\mathrm{t}=2.65 ; \mathrm{p}=.010)$ and, according to the standardized coefficient representing the relative contribution of the independent variable, the ability to express creatively is influenced in the order of instantly and communicability.

\subsection{Effect of digital natives network homogeneity on creative expressive ability}


Regression results of network homogeneity with respect to creative expressive ability are shown in [Table 5].

Table 4. Analysis summary of the impact of media utilization on creative expressive ability $(n=303)$

\begin{tabular}{|c|c|c|c|c|c|}
\hline \multirow{2}{*}{$\begin{array}{l}\text { Independent } \\
\text { variable }\end{array}$} & \multirow{2}{*}{$\begin{array}{l}\text { Dependent } \\
\text { variable }\end{array}$} & \multicolumn{2}{|c|}{$\begin{array}{l}\text { Unstandardized regression } \\
\text { coefficients }\end{array}$} & \multirow{2}{*}{$\begin{array}{c}\begin{array}{c}\text { Standardized } \\
\text { regression } \\
\text { coefficients }\end{array} \\
\beta\end{array}$} & \multirow{2}{*}{$\mathrm{t}(\mathrm{p})$} \\
\hline & & B & Standard error & & \\
\hline (constant) & \multirow{3}{*}{$\begin{array}{l}\text { Creative } \\
\text { expressive } \\
\text { ability }\end{array}$} & 3.073 & .346 & & $8.889(.000)$ \\
\hline Instantly & & .450 & .115 & .523 & $3.914(.000)$ \\
\hline Communicability & & .267 & .101 & .354 & $2.655(.010)$ \\
\hline
\end{tabular}

Table 5. Analysis of variance $(n=303)$

\begin{tabular}{|c|c|c|c|c|c|}
\hline & Sum of squares & $\mathrm{df}$ & Mean square & $\mathrm{F}$ & $\mathrm{p}$ \\
\hline Regression Model & 5.190 & 2 & 2.595 & 5.733 & .005 \\
\hline Residual & 36.213 & 80 & .453 & & \\
\hline Total & 41.404 & 82 & & & \\
\hline$R^{2}\left(\right.$ adj. $\left.R^{2}\right)=.125(.103)$
\end{tabular}

As a result of the statistical significance test of a model that measures the influence of creative expressive ability with three independent variables, network utilization strength, ideological homogeneity, social homogeneity, and ideological homogeneity, which are subfactors of network homogeneity, was excluded because it was not significant. Also, the F statistic values of the model, which includes the strength of network utilization and social homogeneity, are 5.733 and the significant probability is .005 , and the independent variables included in the model are significantly described in the significance level of .05 . Twelve percent of the total change in creative expression capability $(10 \%$ according to the modulus of modification) is explained by the independent variables included in the model. However, although network utilization strength and social homogeneity are independent variables that affect creative expression ability among the sub-factors of network homogeneity, generalizing the results of the study requires caution as it can be predicted around $10 \%$. Therefore, I can see that in the case of network homogeneity of digital native, the influence on creative expression is low.

Also, the contribution of individual independent variables to network homogeneity to creative expressive ability and the statistical significance analysis results are shown in [Table 6.]

As a result of testing the contribution and statistical significance of the dependent variables of individual independent variables, the independent variables that significantly affect the creative expressive ability at a significant level of .05 are SNS utilization strength $(t=3.38$, $\mathrm{p}=) .001)$, social homogeneity $(\mathrm{t}=2.20, \mathrm{p}=.030)$ and, according to the standardization coefficient, which shows the relative contribution of the independent variable, the SNS utilization strength, and social homogeneity are influencing the creative expressive ability in the order of the network utilization strength and social homogeneity. 
Table 6. Analysis summary of the impact of network homogeneity on creative expressive ability $(\mathrm{n}=303)$

\begin{tabular}{|c|c|c|c|c|c|}
\hline \multirow{2}{*}{$\begin{array}{l}\text { Independent } \\
\text { variable }\end{array}$} & \multirow{2}{*}{$\begin{array}{l}\text { Dependent } \\
\text { variable }\end{array}$} & \multicolumn{2}{|c|}{$\begin{array}{l}\text { Unstandardized regression } \\
\text { coefficients }\end{array}$} & \multirow{2}{*}{$\begin{array}{c}\text { Standardized } \\
\text { regression } \\
\text { coefficients }\end{array}$} & \multirow{2}{*}{$t(p)$} \\
\hline & & B & Standard error & & \\
\hline (constant) & \multirow{3}{*}{$\begin{array}{l}\text { Creative } \\
\text { expressive } \\
\text { ability }\end{array}$} & 3.427 & .232 & & $14.740(.000)$ \\
\hline $\begin{array}{l}\text { SNS utilization } \\
\text { strength }\end{array}$ & & .327 & .097 & .498 & $3.38(.001)$ \\
\hline $\begin{array}{c}\text { Social } \\
\text { homogeneity }\end{array}$ & & .200 & .091 & .326 & $2.209(.030)$ \\
\hline
\end{tabular}

\section{Conclusion}

This study conducted a digital content development class for digital natives in the open innovation paradigm to analyze the differences in creative expressive ability before and after education and analyzed which factors influence creative expressive ability among the characteristics of digital natives, media utilization, and network homogeneity factors. The results of this study are as follows.

First, as a result of analyzing the impact of media utilization on the creative expressive ability of digital natives, it was found that among the sub-factors of media utilization, immediateness and communication have less impact on creative expressive ability. Second, after analyzing the impact of network homogeneity of digital natives on creative expressive ability, the results showed that among the sub-factors of network homogeneity, network utilization intensity and social homogeneity have less impact on creative expressive ability.

Therefore, through research results that creative expressive ability is promoted when using digital native's media, technical and educational approaches to media utilization should be taken to enhance instantly and communication rather than immersion and expressiveness.

\section{References}

[1] N. Georgescu-Roegen, "Nicholas Georgescu-Roegen about Himself," In: Szenberg M (ed), Eminent Economists: Their Life Philosophies. Cambridge, UK, Cambridge University Press, pp.128-159, (1992)

[2] Eun-young Na, "Differences in the Perception of reality between middle-aged and long-term users of SNS: Cultivation effect and convention effect," Journal of Korean Psychology: Social and Personality, vol.26, no.3, pp.63-84, (2012)

[3] C. R. Sunstein, "Empirically Informed Regulation," University of Chicago Law Review, vol.78, no.4., pp.13-03, (2011)

[4] S. Norris, "Personal identity construction: A multimodal perspective, invited paper presented at the international roundtable on discourse analysis at city university," Hong Kong, pp.21-23, Apr., (2005)

[5] Corte. V. D., "Innovation through coopetition: Future directions and new challenges," J. Open Innov. Technol. Mark. Complex, vol.4, no.4, pp.47, (2018), DOI: https://doi.org/10.3390/joitmc4040047

[6] Andreas Pyka, Kristina Bogner, and Sophie Urmetzer, "Productivity slowdown, exhausted opportunities and the power of human ingenuity-Schumpeter meets georgescu-roegen," J. Open Innov. Technol. Mark. Complex, vol.5, no.3, pp.39, pp.1-17, (2019)

[7] J. W. Dimmick, T. A. McCain, and W. T. Bolton, "Media use and the life span: Notes on theory and method. American Behavioral Scientist," vol.23, pp.7-31, (1979)

[8] J. Harwood, "Understanding communication and aging: Developing knowledge and awareness," Thousand Oaks, CA: Sage Publications, (2007) 
[9] D. Gauntlett and A. Hill, "TV living: Television, culture and everyday life," New York, NY: Routledge, (1999)

[10] H. Vandebosch and S. Eggermont, "Elderly people's media use: At the crossroads of personal and societal developments," Communications, vol.27, pp.437-455, (2002)

[11] M. Prensky, "Digital nativess, digital immigrants," Part 1, On the horizon, Sept., (2001)

[12] A. Williams, Move over, millennials, here comes Generation Z. The New York Times. 2015, Retrieved March 16, 2018 from www.nyti]mes.com/2015/09/20/fashion/move-overmillennials-here-comes-generationz.html

[13] C. Sterbenz, "How will the next generation use technology?" World Economic Forum, Retrieved March 16, 2018 from https://www.weforum.org/agenda/2015/12/how-will-the-next-generation-use-technology/

[14] Y. M. Hwang, "The effects of tendency at digital nativess on tourism behavior," DongMyeong University a master's thesis, (2009)

[15] E. K. Na, "Online and offline world interaction. korean journal of journalism \& communication studies," vol.51, no.4, pp.7-48, (2007)

[16] J. H. Ryu \& D. H. Lee, "An investigative study on political communication in microblog publication as social media,” Korean Journal of Journalism \& Communication Studies, vol.55, no.4, pp.309-330, (2011) 
This page is empty by intention. 